leisure, it might take a year for the presidents of state soeieties to get a staff in line for suel work, unless volunteers eome forward.

It seens to me that preeisely this kind of service is possible for our married members, of whom we must have hundreds all over the country. Many are niarried to pliysicians, and we should be able to look to them for the lion's slare of this preliminary inquiry.

I hope, also that every state society will eonsider this projected and really vast undertaking at its next meeting, for it will require the eoöperation of all to be pushed through. Those states espeeially which have gained their legislation may have opportunity to devote considerable time to ways and means-shonld begin by re-reading Mrs. Crane's and Mrs. Lupinski's articles, and then work at systematizing dinta regarding almshouses in their states.

Work of this nature has already been undertaken by nursesnamely our publie-spirited and altruistie leaders in Virginia, Miss Cabaniss and her en-workers. Some five years ago they attempted to reseue the sick of the alushomse, and lave actually sueceeded in placing one gradunte nurse there in charge, and have secured good and kind women to work as assistants.

It is also interesting in this conmetion to note the erusade now being eondueted in England by Mrs. Bedford Fenwiek and the Matrons Couneil for skilled nursing in prisons. 'The spirit of melfish devotion still lives in our profession, even thougl the modern spirit of eommereialism may not be denied, and if our great and wide-spread associations determine to ehampion the eanse of the almshouse and prison patients, in eoopperation with that tremendous army of elul women, potent for good, we may all feel sure that it is possible to do for them just what has been done for the hospitals.

\title{
AMUSING INCIDENTS OF A SCHOOL NURSE
}

BY S. W. N.

Philadelphin.

To the nurse and doetor alike in their drama-like eareers, it is the interspersing of the comely and amusing imeidents, that prevent the continuous watching of others suffer, from playing on their nerves. It aets as a check valve against monotony. A few small tales in the life of a school nurse, may prove interesting and instructive.

The following amusing ineident shows the strategy of the nurse. in euring a bad ease of uneleanliness. There was a boy in one of the 
lower grades, who persistently eame to school dirty, even though on several occasions he was sent home with a note to his parents, requesting their attention to his condition. It met with no response, so the nurse had the boy mect her at the end of the session. She accompanied him to his home, and seolded the mother for her negleet. She then proceeded to give the child the much needed bath as an instruction to the parent. The mother seemed delighted to watch the nurse give her boy such a thorough cleaning, that was going to relieve her of the job of a similar operation for the next six months. When the nurse finished, she compelled the mother to pay her ten cents for carfare, the usual charge of a visiting nurse. The parent reluctantly paid the fee, and upbraided the child for not keeping elean. The fear of another visit from the nurse, with an outlay of ten cents, has caused the parent to keep a careful watch on the child's cleanliness evcr sinee.

Another child who was extremely dirty was taken home by the nurse, and the mother was asked to show how she washed him, as she insisted that she bathed him every morning. She vanished from the room and returned in a few moments with a teacupful of water. She drew the child close to her, and proceeded with her so-called daily bath. After placing her laand in the teacup, she rubbed it wet over the child's face, and proudly proclaimed to the nursc, "and I do it every day." The nurse's mention of a bath tub, wash rag, etc., was a revelation.

In contrast to this conservative mother was a strenuous Italian woman who, when informed that her child necded a bath, unceremoniously pulled off the boy's dirty sweater, and carried him to the hydrant in the alley. She then held the frightened lad under the full force of the stream, and ran a whole new bar of soap, grasped firmly in the other hand, up and down the child's back. The picture put to shame the famous advertisement of a certain soap, "You Dirty Boy!" Her method would have been effective, had she not dried him with the end of her dirty skirt.

It is surprising how children become attached to a nurse, and are anxious to be sent to her for treatment. They will come to her on the slightest pretence of an ailment, and sometimes these excuses are amusing. One child said her mother had a headache. Another claimed he fell out of bed and wanted some medicine to prevent such occurrences. Questions are asked such as "Mother wants something to cure baby": toothache." A number of children beg permission from their teachers to be sent to the nursc, and examination proves a scratch that would require the use of a magnifying glass to detect. The appreciation from these youthful patients is sometimes impressing and gratifying, and is 
often shared by the parents. A child who suffered for a long time from a bad eczema, and who was cured by the attentions of the nurse, prescnted her with a small ivory locket crudely carved by his father. Letters of thanks and gratitude from parents are numerous. The comhination of spelling which would be approved by the " Revised Spelling Commission" and a disregard for grammar, make some interesting and pathetic reading. The following is a sample:

Der nurs:-I lov yu becos yu mak well mi Mary. It is gud that de schul has such a gud womin to luk after de childen, my usbend tanks yu to. God bless yu.

Mrs.

Small trinkets and gifts at Christmas are numerous. I was never more impressed by the appreciation shown by these children, than on a visit to Baltimore. The nurse, whose birthday was on that day, was the recipient of flowers, potted plants, and small gifts from many of the children who felt her gentle kindness in moments of need. To them she is truly the "Visiting Angel of the School."

Possibly many doctors and nurses have noticed that whenever a child is asked to put out its tongue to have its throat examined, he involuntarily at the same time stretches both arms away from his sides. and widely separates his fingers.

Two Russian boys, brothers, were sent to the visiting physician, with a note from the teacher, stating that these children must be nearsighted as they see nothing on the blackboards, and only gaze wildly at the books. The boys were placed fiftcen feet from a test card of letters, and were asked to read. Their reading, in badly broken Fnglish, and the naming of any letter that came foremost in the mind, showed they were guessing. On questioning them, they said they had been only three months in this country, and as yct knew no English. A test card of Jewish letters was substituted for the English one, and with grace and ease the proud youngsters read the smallest type. A letter was sent to their teacher, stating that the boys were unacquainted with the English language, but if given three more months, would head their class.

A child of the second grade was being examined for its vision, before a test card. He apparently had defective eyesight or did not know the letters. "Don't you know you ABCs?" was asked by the physician "No." "How long have you becn in school?" "Three years." "Three years in school, and don't know your letters?" "No, and you come to the school every day and don't know how many steps you climb." 
While we agree that the poor will always be among us, the school nurse will not agree with one of the mothers who tried to impress her that vermin is a necessary neighbor. The nurse sent for the mother of a child with an unclean head that was receiving no attention. The mother asked the reason for sending for her, and when informed her child had vermin in her hair, answered: "Is that why you sent for me? that is nothing, every one has some of them."

That both the doctor and the nurse must be most explicit and plain in their instructions to a patient or the attendant is shown bv the following incident. A visiting nurse was informed by a mother that the doctor had ordered suppositories for her baby, one to be inserted into the rectum every two hours, but the things did not melt as the doctor said they would. The nurse asked to see the suppositories and to be shown how the mother inserted them. She found that the druggist had dispensed them in small glass vials to kcep them from melting, and the parcnt had inscrted vial and all. Fortunately only four hours had elapsed, and the physician had only two vials to extract.

\section{RED CROSS WORK}

Trre annual meeting of the Connecticut Branch of the American National Red Cross was held at Hartford, Connecticut, on November 18. The trcasurer reported that thirty-four hundred and ejghty-seven dollars and ninety-four cents had been received, and that twenty-eight hundrcd and fourtcen dollars and thirty-six cents had been expended, cither in relief work or as contributions to the Central Red Cross treasury, with thc exception of a small amount needed for administration expense.

Five graduatc, registered nurses had been added to the enrollment during the year, making a total enrollment for the state of fifteen. Fach nurse is furnished by the National Society with a handsome badge on which her name and national number arc engraved, and, when accidents occur, thesc batges will doubtless bc of service to the wearers, guarantceing thcir official position, compelling recognition, and making it possible for them to give competent first aid to the injured.

The report illustrates the importance of these badges with one or two instances. One was that of a Red Cross nurse who went to the scene of a trolley accident and, having no badge, was not allowed to go to work until she was, by chance, recognized by one of the physicians. A member of the state board of examination and registration of nurscs says that the Red Cross badge is the best letter of introduction which a 